\title{
Temarecension: Svenska kyrkan och samerna - en mörk historia
}

\author{
De historiska relationerna mellan Svenska kyrkan och samerna. \\ En vetenskaplig antologi \\ Daniel Lindmark \& Olle Sundström (red.)
}

Artos, 2016. $1135 \mathrm{~s}$.

Samerna och svenska kyrkan. Underlag för kyrkligt försoningsarbete

Daniel Lindmark \& Olle Sundström (red.)

Gidlunds, 2017, 217 s.

Sensommaren 2019 meddelade regeringen att den hade för avsikt att i samarbete med Sametinget etablera en sanningskommission rörande relationen mellan den svenska staten och samerna. Ett mångårigt krav från Sametinget, politiker, Amnesty International med flera hade till sist gett resultat. För regeringen var det "en viktig och prioriterad fråga för att söka kunskap om historien och dess samband med dagens villkor för samerna". Statssekreterare Helene Öberg sade i ett tal 2org: "Den statliga politiken har i många fall bidragit till att samerna fråntagits sitt språk, sin kultur och sin identitet. Detta är fortfarande ett öppet sår och påverkar relationen mellan samer och staten och mellan olika samiska grupper." På sikt hoppades regeringen att sanningskommissionens arbete skulle leda till "försoning och helande".

Sanningskommissioner, men också närliggande vitboksprojekt, har sedan I990-talet blivit vanliga världen över och gett upphov till talet om vår tid som "ursäkternas tidsålder". Sanningskommissionernas officiella mål är att utifrån ett dagsaktuellt politiskt behov undersöka det förflutna i syfte att ge de drabbade, eller deras efterlevande, någon form av ursäkt, upprättelse, kompensation eller liknande. I utredningsarbetet involveras ofta vetenskapliga experter. Erfarenheterna visar att deras deltagande omfattar betydande utmaningar. En av de mest uppenbara är svårigheterna att hantera risken för anakronism, det vill säga att vår tids normer tas som utgångspunkt vid en värdering av hur människor och institutioner agerade förr. En annan 
svårighet rör sanningsbegreppet och de förväntningar som väcks hos många när sanningskommissioner/vitboksprojekt startar sitt arbete - då ska sanningen med stort $\mathrm{S}$ grävas fram i arkivens gömmor.

År 2016 presenterades vitboken De historiska relationerna mellan Svenska kyrkan och samerna. En vetenskaplig antologi (hädanefter HKS), med Daniel Lindmark och Olle Sundström som redaktörer. HKS omfattar närmare I 200 sidor bestående av 33 artiklar fördelade på två band. I vitboksprojektet ingår också en sammanfattande och försoningspraktiskt inriktad bok, Samerna och svenska kyrkan. Underlag för kyrkligt försoningsarbete (hädanefter SK), utgiven 20I7, även denna redigerad av Lindmark och Sundström.

HKS var resultatet av ett fyraårigt forskningsprojekt lett av forskare vid Umeå universitet och finansierat av Svenska kyrkan. Det övergripande ansvaret hade en styrgrupp tillsatt 20I2, där sex av åtta var kopplade till Svenska kyrkan och/eller dess Samiska råd. Styrgruppen formulerade vitboksprojektets syfte, som var att

\footnotetext{
dokumentera, presentera och diskutera vilket utbyte samerna har haft av kyrkans verksamhet, på både gott och ont. Särskild uppmärksamhet ska ägnas åt problematiska inslag, det vill säga, beslut, handlingar, verksamheter och strukturer som utsatt samer för kränkande behandling av olika slag, oavsett om dessa kan rubriceras som tvång, förtryck, diskriminering eller rasism. (HKS, s. 29)
}

HKS uppmärksammades stort i medierna 20I6, men har inte - med ett undantag - erhållit några recensioner eller blivit föremål för någon inomvetenskaplig granskning. ${ }^{2}$ Kanske avskräcker omfånget och dess tvärvetenskapliga karaktär. Och givetvis är det omöjligt att i en temarecension som denna referera och värdera innehållet i alla 33 artiklar och SK:s tio kapitel. Jag inleder med en översiktlig beskrivning av innehållet i böckerna men utöver detta diskuteras kritiskt HKS:s teologisk-kyrkliga inbäddning samtidigt som den gör anspråk på att vara strikt vetenskaplig, en vetenskaplig antologi som vilken som helst. Vitboksprojektet visar på några av de utmaningar som också statens sanningskommission kommer att möta, vilket avslutningsvis kommenteras.

\section{Kort om innehållet}

HKS är indelad i fem teman. Det första, "Perspektiv på försoning”, behandlar försoningsprocesser teologiskt och vetenskapligt och de erfarenheter som vunnits ur de som ägt rum, nationellt och internationellt. Det andra temat, "Mission och skola", behandlar Svenska kyrkans insatser inom 
utbildningsområdet och hur det påverkat samer från medeltiden fram till igoo-talet. Det tredje temat "Kyrkan och samiska kulturella uttryck" uppmärksammar de intensifierade försöken från kyrkans sida att mot slutet av I6oo-talet utrota samers bruk av trummor, jojk, heliga platser och det samiska namnskicket. I det fjärde temablocket "Samerna och kyrkan som myndighet" behandlas bland annat kyrkans involvering i folkbokföring, markförvärv och rasbiologisk forskning. Boken avslutas med temat "Kyrka och samer utanför Svenska kyrkan" vilket redovisar kyrka-same-relationer i de norska och finska delarna av Sápmi, samt något om det frikyrkliga engagemanget visavi samer i Sverige. Merparten av utrymmet i SK ägnas åt Björn Norlins och David Sjögrens sammanfattningar av artiklarna i HKS. Nytt är däremot de tre avslutande kapitlen som har en försoningsinriktad, teologisk-kyrklig karaktär.

HKS:s huvudresultat är att Svenska kyrkan haft ett betydande maktövertag gentemot samerna och inte i tillräckligt hög grad respekterat deras religiösa trosuppfattningar/praktiker och kulturyttringar. Kyrkan har, som det kallas i en av artiklarna, deltagit i ett "kulturmord" (HKS, s. 5I). Det är alltså en mörk bild som ges, vilket också kommenteras av Norlin och Sjögren i SK: "Som läsare kan man ibland, med fog, undra om kyrkan verkligen gjorde allt galet" (SK s. 98).

\section{Vitboksprojektets teologisk-kyrkliga inramning}

Det första som möter läsaren i HKS är ärkebiskop Antje Jackeléns förord om behovet av självrannsakan och om vikten av att nå fram till upprättelse och försonande: "Såren, smärtan, skammen, självföraktet, vreden och alla svåra minnen är verkliga. De kan inte nonchaleras av en kyrka som vill leva i Jesu Kristi efterföljd." Och på samma sida: "När vi har svikit det samiska folket, har vi också svikit oss själva och Gud." Det handlar nu om att "lära sig av tidigare generationers misstag" och inte exempelvis väja för att avslöja "intressekonflikter". Jackelén betonar att det försoningsarbete som pågått mellan Svenska kyrkan och samerna sedan r99o-talet med den färdigställda HKS nu kan fortsätta: "uppgörelsen med en historia av kolonialism, benämnandet av ondska och smärta och mobiliseringen av viljan att bygga ömsesidiga, respektfulla och rättvisa relationer” (HKS, s. II-I2).

Redaktörerna Lindmark och Sundström betonar inledningsvis HKS:s vetenskapliga status och att artiklarna kvalitetsgranskats enligt de normer som gäller inom akademin. Samtidigt framhålls att HKS "ska förstås mot bakgrund av det försoningsarbete" som pågått i decennier. De inbjudna författarna har informerats om "vitboksprojektet och dess ambitioner", vilket rimligen inkluderar dess funktion i försoningsarbetet. Författarna har valts 
med utgångspunkt $\mathrm{i}$ de teman som styrgruppen och redaktörerna identifierat som särskilt viktiga att behandla (HKS, s. 35 ff.). I SK betonar redaktörerna att vitboksprojektet och dess publikationer i sin helhet kan "förstås som en del av ett erkännande, ett försök att tala sanning om det som hänt $\mathrm{i}$ historien”. Samtidigt deklareras motsägelsefullt att forskarna "inte behövt förhålla sig till den försoningsprocess som projektet som helhet är tänkt att bidra till” (HKS, s. 20-2I). Förmodligen avses forskarnas frihet att själva välja teorier och metoder, vilket inte utesluter en anpassning till vitbokens funktion i försoningsprocessen. Jackeléns förväntningar på författarna var i varje fall entydiga: "Författarnas uppdrag har varit att lyfta fram i ljuset de kränkningar och oförrätter som tidigare sopats under mattan” (HKS, s. I2).

Vitboksprojektets teologisk-kyrkliga inramning förstärks av artiklarna i HKS:s inledande tema där författarna visar på försonings- och botgöringspraktikernas starka ställning i den kristna traditionen, teologiskt och kyrkohistoriskt. Mellanmänskliga relationer är enligt denna tradition viktiga men viktigast ändå är den vertikala relationen människa-gud, som det uttrycks av Carola Nordbäck i en artikel: "För att kunna försonas med Gud måste människan först försonas med sin nästa" (HKS, s. 79-I20). Det dubbla försonandet innebär, när det som här överförs till en institutionell och kollektiv urfolksnivå, att den svenska kyrkans ledning och dess medlemmar söker försonas med samerna för att därigenom försonas med Gud.

\section{Tros- och kulturskifte}

I några av HKS:s artiklar behandlas ingående kyrkans offensiv mot samerna och deras naturreligion mot slutet av I6oo-talet. Här beskrivs jakten på trummor, nåjder och kultplatser och den respektlöshet och inhumana behandling som en del kristna präster kunde visa de samer som satte sig på tvären och ibland även kombinerade kristen tro med att parallellt och $\mathrm{i}$ hemlighet utöva vissa delar av naturreligionen. Det omvända kristna livet hade också, nämns det i förbifarten, positiva sidor då prästernas själavårdsarbete kunde ge samer tröst och stöd. På en urfolklig, kollektiv och kulturell nivå är dock budskapet i HKS glasklart: kristnandet av samer var inte enbart ett trosskifte utan också ett kulturskifte. Det rörde sig om utövandet av en kulturell övermakt, om hur den svenska kolonialmakten med dess ideologiska överbyggnad - där den kristna religionen hade en framträdande plats - i grunden omformade den samiska kulturen och dess gemenskaper. Gunlög Fur beskriver det som ett ojämlikt kulturmöte med förödande konsekvenser som gör sig påminda än idag (HKS, s. 274-275).

Kristnandet av "hedningar" och strävandet att utvidga "guds rike på jorden” var, och är, en grundbult i den kristna tron, även i Svenska kyrkan. 
Det är sannolikt också därför som HKS och dess författare formulerar sig försiktigt och inte egentligen uttrycker någon kritik av missionsverksamheten i sig. Svenska kyrkans kyrkoordning stadgar idag att missionsverksamheten är en av dess grundläggande uppgifter. Inom Evangeliska Fosterlandsstiftelsen, en inomkyrklig väckelserörelse, tolkas kyrkoordningen som att det också gäller den internationella missionen och att det är "en mänsklig rättighet” att få ta del av det kristna budskapet. Svenska kyrkans uppfattning om missionens roll idag - och att det exempelvis är rätt och riktigt att $\mathrm{i}$ nuet omvända urfolk - innebär att missionsverksamheten rörande samer för 300-400 år sedan också betraktas som något i grunden positivt. Vissa inslag kan kritiseras, men inte kristnandet i sig, trots att det innebar att en folkgrupps kulturella särart förändrades i grunden.

Av de artiklar som behandlar försoningsprocessens religionshistoriska och teologiska dimensioner framgår också att vitboksprojektet ytterst handlar om att inom Svenska kyrkans ram lägga grunden för en ny och nutida religiös gemenskap mellan samer och dem med andra etniciteter än "majoritetsbefolkningen”. Det är också uttryck för en ekumenisk strömning inom Svenska kyrkan som de senaste decennierna betonat andligt syskonskap över religionsgränser. Vitboken framstår därmed också som en föreningsintern produkt, vilket samtidigt är en distinktion som är svår att upprätthålla då mycket av den svenska statens relationer med samer, och andra medborgare, gick via dess präster verksamma ute i landet.

\section{Förövare-offer}

Vitboksprojektets uppdrag förklaras vara att särskilt uppmärksamma "problematiska inslag" i Svenska kyrkans relation till samer. Men det är också viktigt att ge en "rättvisande bild" av kyrkans positiva insatser. Som exempel nämns dess arbete med att skapa skriftspråk och litteratur för de samiska varieteterna, vilket också, tillsammans med åldringsvården för samer, är teman i några artiklar. Men det är alltså undantag, och ambitionen att ge en "rättvisande bild" av de positiva insatserna har inte satt några starkare avtryck i HKS som i stället domineras av det "problematiska", som också blir det tema som knyter samman artiklarna.

Vitboksprojektets teologisk-kyrkliga inramning - och dess tvåtusenåriga botgörings- och bekännelsekultur - är sannolikt ett skäl till att det negativa dominerar. Den harmoniserar även med det "idealistiska offerperspektivet", som det kallats inom etnicitets- och migrationsforskningen, ${ }^{3}$ som enligt min mening också återfinns inom delar av den postkolonialt präglade forskningen om samer i Sverige och som finns representerad i några av HKS:s artiklar.

Här finns även den framträdande dikotomin förövare-offer som bidrar till 
tämligen svart-vita beskrivningar och analyser, och till att samer framstår som passiva aktörer. Särskilt svårhanterbara blir alla de tusentals individer som inte enkelt kan placeras i endera kategorin. Det gäller exempelvis de präster, kateketer, lärare med flera som hade samiskt påbrå men gick Svenska kyrkans och statens ärenden. De bör rimligen, med sina språkkunskaper och möjligheter att upprätta förtroliga relationer med samer, ha tillhört de mest effektiva utrotarna av särpräglad samisk kultur. Deras agerande beskrivs utförligt medan analyserna om hur deras agerande ska förstås historiskt och samhälleligt kretsar kring frågor som rörde deras individuella kvalifikationer, empatiska förmågor, samt om de - och här avses främst prästerna - agerade som statliga tjänstemän eller i rollen som kyrkans tjänare när det "problematiska" utfördes. Å ena sidan förklaras att en dylik uppdelning ofta är omöjlig att göra i efterhand, och knappast heller meningsfull. Å andra sidan förs långa diskussioner som indikerar att författarna menar motsatsen: att prästerna ibland agerade som kyrkans tjänare, andra gånger som statliga tjänstepersoner, och ibland kanske också som privatpersoner.

I kategorin förövare placeras också den högabstrakta kategorin "majoritetssamhället" som på olika sätt deltagit i de historiska övergreppen mot samer. I majoritetssamhället inkluderas alla icke-samer och deras gemenskaper, institutioner med mera. Det betyder exempelvis att antirasistiska socialister som för 80-I20 år sedan kämpade mot dåtidens rasism och politiska konservatism, och för vilka Svenska kyrkan oftast framstod som en aktiv motståndare, förs samman i en och samma kategori - nämligen majoritetssamhället - som Norrbottensbiskopen Olof Bergkvist (mångårig riksdagsman för Nationella partiet och en huvudperson i flera artiklar). I7oo-talets backstugusittare, fattighjon, pigor och drängar med flera tillhörde också majoritetssamhället. Användandet av begreppet majoritetssamhället, och vidhängande resonemang om historiska övergrepp, leder till grovkorniga analyser av samhällsprocesser av politisk och kulturell karaktär. Att Svenska kyrkans präster också var politiska subjekt, och vanligen socialkonservativa sådana, framstår som en främmande tanke i HKS.

Några av HKS:s starkaste artiklar behandlar kyrkans medverkan i den rasbiologiska forskningen, med fokus på några präster i Norrbotten, men också dess hantering av mänskliga kvarlevor. Här liksom i många andra artiklar saknar jag en bredare samhällelig kontextualisering av det som behandlas. Rasbiologin uppfattades för omkring hundra år sedan på ett annat sätt än idag, och vetenskap var över huvud taget ett nytt och respektingivande samhällsfenomen. Då kunde exempelvis även samer tala om ”den lappska rasen"4 och uttrycka sig positivt om den rasbiologiska forskningen. Vid samernas landsmöte i Östersund I9I8, ett viktigt steg i samernas etnopolitiska mobilisering, antogs enhälligt en resolution rörande samernas 
bosättningsfråga där man efterlyste "kompletterande undersökningar av statistisk och rasbiologisk art". ${ }^{5}$ Och när den samepolitiska företrädaren Gustav Park vid samma tid kommenterade språkvetaren K.B. Wiklunds arbete med att författa läroböcker till nomadskolan betonades att Wiklund inte fick utelämna avsnitt om "den rasbiologiska vetenskapens tillämpningar på samerna”. ${ }^{6}$ Det tidsbundna i dessa föreställningar och hur de omfattades av olika aktörer borde alltså ha belysts bättre. Men kanske visar den dekontextualiserande hållningen på ett mer allmänt fenomen inom vitboksoch sanningskommissionsgenren.?

\section{Varför gjorde kyrkan "allt galet"?}

Ett av HKS:s viktigaste resultat är, som nämnts, att Svenska kyrkan varit resursstark och haft ett stort maktövertag. Få torde invända mot denna slutsats. På frågan varför kyrkan under närmare tusen år verkar ha gjort "allt galet" ges inget entydigt svar. Ett huvudskäl är att många artiklar är relativt beskrivande och inte tydligt knyter an till teorier om samhällsförändringar och religion eller religiösa samfund. En återkommande tematik, med förklaringskraftsambitioner, är att statskyrkosystemet försvårade ett självständigt agerande från Svenska kyrkans sida. Den var dessutom länge svagt organiserad med otydliga beslutsprocesser. Jag tolkar tankegångarna som att en självständig kyrka med bra beslutsprocesser sannolikt skulle ha agerat annorlunda mot samerna, mer i samklang med dagens kristna värdegrund.

Andra svar på varförgickdetgalet-frågan är mer idealistiska och anakronistiska. Lindmark och Sundström skriver exempelvis, när de ska sammanfatta HKS, att Svenska kyrkan och dess präster inte "lyssnat" på samer i tillräcklig utsträckning (HKS, s. I I30-I I34). Ett närliggande synsätt finns hos Johannes Marainen som beklagar att den svenska kyrkan "genom århundrandena tagit sig friheten att bestämma över samers namngivning" (HKS, s. 8I7). Hans Mebius menar för sin del att det handlar om en "tidigare brist på engagemang" hos kyrkan/prästerna (HKS, s. 704). Hos Maja Hagerman är det moderniteten och upplysningens ideal och attraktionskraft som förklarar de norrbottniska prästernas stöd till rasbiologin. De "tycks [inte ha] haft kritisk distans nog för att se rörelsens grundvärderingar om människors olika värde och att en förnuftsstyrd 'människoproduktion' står i strid med en kristen värdegrund” (HKS, s. 986). Den kristna värdegrunden är alltså något överhistoriskt och oföränderligt. Hos några artikelförfattare framställs kyrkans, och prästernas, agerande som något "anmärkningsvärt", underförstått att de borde inte ha gjort så eftersom de var präster (HKS, s. 954). 
I många av vitboksprojektets artiklar och i de sammanfattande resonemangen framträder en organisk samhällssyn där samhället tänks bestå av individer och gemenskaper vars intressen harmoniskt ska balanseras på ett förnuftigt och respektfullt sätt. Det sistnämnda ska ske genom den vägledning som den kristna värdegrunden ger och/eller genom läsning av Bibeln. Historiska "oförrätter" sker enligt detta synsätt på grund av oförnuft, ondska, bristande respekt och av en otillräcklig förståelse av de kristna urkunderna, förkunnelsen och den samlade värdegrunden. Kyrkans maktresurser och övertag gentemot samer (och andra) ska hanteras förnuftigt.

HKS:s organiska samhällssyn innehåller även ett naturrättsligt tänkande, integrerat med ett mer modernt rättighetstänkande, där individer och folkgrupper själva har suverän rätt att bestämma sina egna livsvillkor. Den svenska nationalstaten kan också i enlighet med den organiska samhällssynen tillskrivas mänskliga känslor och tillkortakommanden: "Sverige" skäms över sin mörka historia, övergreppen mot samer och så vidare. Det representerar ett mystifierande och spekulativt inslag i svensk historieforskning sedan ig9o-talet. ${ }^{8}$

\section{Avslutning}

Svenska kyrkans vitboksprojekt ger en mycket kritisk beskrivning och analys av de historiska relationerna mellan kyrkan och samer, indirekt också av relationerna mellan staten och samer. Några viktiga skäl är dess avsiktliga fokus på det "problematiska", förövare/offer-dikotomin, den organiska samhällssynen, den idealistiska värdeanakronismen och att det harmoniserar med försonings- och botgöringspraktikernas starka ställning i den kristna traditionen. ${ }^{9}$ Det anakronistiska dilemmat diskuteras visserligen ingående och balanserat av redaktörerna men har inte avhållit dem och andra från att formulera just anakronistiska utsagor.

Kyrkans beredvillighet att kritiskt granska sin medverkan i övergrepp för hundratals år sedan, samt forskares intresse att delta och ge legitimitet åt dylikt, har lett till att även andra grupper - till exempel kvinnonätverk rörande häxprocesserna - kräver utredningar och ursäkter. Ett rimligt krav, utifrån ett perspektiv där mänskligt lidande graderas och jämförs. ${ }^{\text {Io }}$ Men det illustrerar också en del av svårigheterna. Historiker kan inte sätta sig till doms över det förflutna och utifrån en nutida etisk kompass avgöra vilka övergrepp som är allvarliga nog för att motivera vitböcker eller sanningskommissioner.

Med tanke på HKS:s vetenskapliga anspråk, och tusenåriga tidsperspektiv, borde den ha getts en tydligare historievetenskaplig inramning (inte som nu främst en teologisk och kyrkohistorisk). Jag saknar alltså en 
övergripande historievetenskaplig problematisering förankrad i tidigare forskning, internationellt och nationellt, lämpligtvis sådan som sysslat med kulturmöten, ackulturationsprocesser och religiösa institutioners roll i dessa, detta i synnerhet som många artiklar saknar vetenskaplig problematisering. Kanske hade ett dylikt angreppssätt kunnat förklara varför så få samer trots allt vänt kyrkan ryggen.

Jag är vidare kritisk till vitboksprojektets många begrepps- och värdeanakronismer samt ointresset för att kritiskt diskutera individuell och kollektiv minnesproduktion rörande samhällsprocesser som ägt rum för hundratals år sedan. Vitboks- och sanningskommissioner som rör händelser i närtid, när involverade ännu finns i livet och dokumentationen är god, är något annat än när man som här hanterar uppemot tusen år av samhällsomvandlingar. Tidsgapet är stort. Det förefaller minst sagt vanskligt att exempelvis hävda ett kausalt samband mellan psykiska ohälsa bland samer idag och den svenska statens (kyrkans) kolonisation från I50o-talet och framåt (SK, s. I63).

Regeringens tillkännagivande av en statlig sanningskommission, samt emottagandet, indikerar att också dess arbete ska fokusera det "problematiska” och att samer även denna gång riskerar att göras till passiva offer. De har, som det sägs, "fråntagits sitt språk, sin kultur och sin identitet". Detta offerperspektiv harmoniserar med en samtida etnopolitisk aktivism och retorik, samt med innehållet i en del postkolonialt präglade studier, men det harmoniserar mindre bra med den äldre forskningen om samers övergång från renskötsel, jakt, fiske till jordbruk och lönearbete. Denna övergång, liksom generellt de materiella livsvillkoren, kan förväntas få en helt annan uppmärksamhet i sanningskommissionen än i HKS med dess fokus på mission, utbildning och kyrkohistoriska frågor. Samers övergång till jordbruk och lönearbete, som sköt fart i mitten av i8oo-talet, var knutet till bland annat befolkningsökning, rennomadismens logik och en ökad konkurrens om naturresurser, men också till den kapitalistiska industrialiseringen som med kraft omdanade samhället, vilket tvingade människor att efter bästa förmåga hantera de nya kraven. Få kunde leva vidare som tidigare generationer gjort; kanske inte heller ville det. ${ }^{\text {II }}$

Idag torde det finnas minst 200 0oo-250 000 individer i Sverige med samiskt påbrå, varav den helt övervägande majoriteten saknar samisk identitet eller koppling till den kulturbärande renskötseln (som idag heltidssysselsätter omkring 500 individer). Det rör sig om komplicerade och utdragna ackulturationsprocesser och folkliga "sammansmältningar" med svåranalyserade push- och pull-faktorer. En nyckelfråga är hur individer från I8oo-talet och framåt - med kanske upplevda dubbla svensk-samiska, eller flytande, hybridiserande etniska identiteter - agerat som politiska subjekt. I vilken utsträckning har de exempelvis via valsedlar och livsföring i övrigt gjort 
motstånd eller understött välfärdspolitiken och dess effektivitetsinriktade näringslivspolitik, nationellt samt lokalt i Norrland? Enligt min mening kan inte en statlig sanningskommission med vetenskapliga anspråk utelämna ett dylikt aktörsorienterat underifrån-perspektiv.

Jonny Hjelm

\section{Noter}

I Regeringen, Tal av statssekreterare Helene Öberg på ceremonin i Lycksele för återbördandet av samiska kvarlevor, 2019, www.regeringen.se/tal/20192/o8/tal-av-helene-oberg-pa-ceremonin-i-lycksele-for-aterbordandet-av-samiska-kvarlevor [hämtad 2020-OI-20].

2 Otso Kortekangas, "The Church of Sweden and the Sámi: Broad Perspectives on History in Reconcilation", Scandinavian Journal of History, 42:3, 20I7, s. 355-359.

3 Kahlid Khayati \& Magnus Dahlstedt, "Diaspora - relationer och gemenskap över gränser", i Migrationens och etnicitetens epok. Kritiska perspektiv i etnicitets- och migrationsstudier, Magnus Dahlstedt \& Anders Neergaard (red.), Stockholm 2013, s. 87-90.

4 Se t.ex. Elsa Laula, Inför lifeller död? Sanningsord i de lappska förhållandena, Stockholm 1904, s. 25 .

5 Ett historiskt möte. Protokollet från samernas landsmöte i Östersund I9I8, Patrik Lantto (red.), Umeå 2018, s. 48-49.

6 Christer Karlsson, "En lärobok för livet. Karl Bernhard Wiklund och Nomadskolans läsebok", i Stat, religion, etnisitet, Björn-Petter Finstad, Lars Ivar Hansen, Henry Minde, Einar Niemi, Hallvard Tjelmeland (red.), Tromsö 1997, s. 235-236.

7 För en diskussion om detta och annat i denna genre, se Berber Bevernage, "The Past is Evil/Evil is Past: On Retrospective Politics, Philosophy of History, and Temporal Manichaeism", History and Theory 54, maj 2015, s. I-20.

8 Se Simon Larsson, "Politiska metaforer i historieskrivningen del 2", under utgivning, Historisk tidskrift 2020:4.

9 Jag avser här helhetsintrycket, vilket betyder att enskilda artiklar kan avvika från det beskrivna mönstret.

Io Debattartikel författad av kvinnonätverket Nordic Noice Movement 2020, Kyrkans tidning 20/I 2020, https://www.kyrkanstidning.se/debatt/minne-av-haxprocesser; https:// www.svt.se/nyheter/lokalt/norrbotten/tornedalingarna-pratar-ut-om-overgreppen.

II Se t.ex. Per Moritz, Fjällfolk. Livsformer och kulturprocesser i Tärna socken under I800-och I900-talen, Umeå 1990. 